\title{
THE UNIVERSITY OF BELIZE STRATEGY FOR COPING WITH COVID-19
}

\author{
Faced with a nationwide lock-down and limited resources, how can the University of Belize \\ successfully achieve its goals?
}

The national university of Belize was forced to close its door on March 20, 2020, due to the deadly pandemic, COVID-19. Its president, Professor Clement Sankat was faced with the challenging decision of how to meet the goals of the university via an electronic means. Previously, he had worked several years as an administrator at the University of the West Indies and, at the time of the pandemic, three years at the University of Belize. Throughout his years of experience, he was required to make challenging decisions - but none was of this sort.

At the time of the pandemic, The University of Belize (UB) had campuses in three of the six districts within the country and served most Belizeans pursuing a bachelor's or master's degree. The student population was diverse. Students had various economic backgrounds, work experience, age, among others.

Several universities throughout the world were faced with similar situations as Professor Sankat, so what made his decision so challenging? Also, many universities had already closed their doors as early as January 2020. As with all other institutions, the University of Belize was required to make quick decisions that would accommodate all its stakeholders. In considering his options, a major part of Professors Sankat's focus was on student-centeredness.

Initially, the president had taken a wait-and-see position while awaiting further guidance and to see how the situation developed. The university then decided to move forward with transitioning to online education and began to apply to the government for further aid. In light of these actions, the president's decisions revolved around developing a strategic plan for the way forward--both to complete the semester and to plan for the start of a new semester in the fall of 2020. So, what was the way forward? How would the president and the university meet the needs of the students? Many were patiently awaiting guidance on the way forward.

\footnotetext{
${ }^{1}$ Copyright (C) 2020, Cindy Thompson. This case was prepared for the purpose of class discussion, and not to illustrate the effective or ineffective handling of an administrative situation. Names and some information have been disguised. This case is published under a Creative Commons BY-NC license. Permission is granted to copy and distribute this case for non-commercial purposes, in both printed and electronic formats.
} 


\section{COVID-19: A Global Pandemic}

COVID-19 was a global pandemic that had impacted many lives worldwide. It had negatively impacted many economies. Due to this pandemic, many businesses had closed, resulting in the loss of jobs. There were also many indirect impacts such as the increase in panic attacks, social issues, and domestic abuse. Several measures had been put in place to cope with this unprecedented situation. For instance, the World Health Organization (WHO) had suggested ways in which employers could protect workers, identified responsibilities of employers, work from home, and how to avoid discrimination, along with many others (International Labour Organization, 2020).

In the academic world, several schools had made a quick and successful transition to conducting education process online (Basilaia, and Kvavadze, 2020). According to Basilaia, and Kvavadze (2020), in Georgia this was possible through online platforms such as Google Meet, Zoom, Slack, and EduPage. Unfortunately, this success was not necessarily typical. The pandemic had necessitated a major transition towards delivering courses online (Reimers, 2020). Hence, the course delivery mode required immediate attention.

\section{Belize}

Belize was a small country located in Central America bordered by Mexico and Guatemala. Its population in 2020 was just over 419,000. Unlike its neighbors, Belize's native language was English, making it an attractive destination for tourists and retirees from the U.S. and Canada. A large part of the country's economy was therefore dependent on the tourism industry (Parks, 2020).

The country of Belize had two main internet service providers: SMART and Belize Telemedia Limited. These service providers extended to most parts of Belize except in the remote areas where only a few individuals resided. Internet was also available via the cable companies. Most Belizeans could access the internet as the internet was available both for installation and could be purchased via data on one's mobile cellphone. The data was relatively cheap as one could purchase 1,024 MB of data for only $\$ 1.99$ Belize dollars.

\section{The University of Belize}

The University of Belize was Belize's National University. The University had campuses in three of the six districts in the country (see Exhibit 1). It served most Belizeans pursuing an associate, bachelor's, master's degree, or certificate program (see Exhibit 2).

Before COVID-19 the University of Belize's aim was to transform the University by placing most of the general courses as well as core courses online (The University of Belize, 2018). This, however, was a major issue as most of the students sign up for face-to-face courses instead. Some of the students believed that they were not prepared for online courses. They believe online learning was more challenging and several of the students did not have internet access at their homes. Due to these student's responses, the University management team decided to offer most of the courses face-to-face.

\section{The Student Population}

The university's student population was comprised of students from various backgrounds including economic status as well as learning capabilities. The university also catered to both part-time as well as full-time students (University of Belize, 2018). Most part-time students were employed. Most of these students were also returning students after several years of being out of school. They normally required a 
refresher on various topics. The diversity of the student population also created disparity within a classroom setting; continuing students were generally at a higher level than returning students. Lecturer would normally have to adjust their lessons to suit the average student.

\section{The University's Financial Situation}

Before COVID-19 the University of Belize was operating at a loss. The most recent financial report 2017-2018 revealed that the University had an operating loss of 1.5 million dollars (University of Belize, 2018). Forty-seven percent of the University's income was generated through tuition and fees while thirty-eight percent were revenues from government support (see Exhibit 3). Seventy-three percent of this income was spent on employee salary and benefits.

At the time of this case, about forty percent of the government's revenue was dependent on the tourism industry (Chow, 2019). The pandemic had therefore created major unemployment for the government and erosion of the tax base. As shown in Exhibit 4, 88.7\% of the government's budgeted revenue was dependent on income, property, international trade $\&$ transactions, and taxes on goods $\&$ services.

Also shown in the Exhibit 4 budget, $43 \%$ of the government's expenditures were on personal emoluments and pensions. Part of this $43 \%$ of government expenditure was distributed to the University of Belize, representing $38 \%$ of the University's income.

Budgetary concerns raised by COVID-19 were not limited to Belize. According to IGI Global (2020), in the United States major cuts in the higher education sector were anticipated, with drastic reductions in funding for activities such as library budgets and academic research expected.

\section{Perspectives on COVID-19 at The University of Belize}

The onset of COVID-19 had resulted in many immediate actions being taken. These actions both involved and significantly impacted the university's stakeholders.

\section{President - Professor Clement Sankat}

The person responsible for making the final decisions at the University of Belize (UB) was the President, Professor Clement Sankat. He was appointed by the Board of Trustees of the University of Belize as its $7^{\text {th }}$ President on February 15, 2017 (The University of Belize, 2018). He retired as Pro-Vice-Chancellor and Campus Principal of The University of the West Indies. He was a Guyanese by birth and resident of Trinidad and Tobago. Since his appointment, he had led the drive for the transformation of the University via a plan entitled, "Transformation Leap-Vision 2022 (see Exhibit 5). This transformation was visible throughout the university. He was focused on student-centeredness, more program introduction, improvement in the building quality, establishing various partnerships, and national and international collaboration. He was a very dynamic and open-minded individual (The University of Belize, 2018).

\section{Professor Sankat's Perspective on COVID-19}

In Professor Sankat's views, March $20^{\text {th }}$ was completely unexpected. It has interrupted the normal running of the University and its impact on Belize and the Central American States. "We had to change gears after Easter break from normal classes", said Professor Sankat. "What should we do after Easter vacation?" "Wait or try to rescue the vast majority of study towards online modality?" At this point, the University of Belize conducted a survey and the university decided to support nearly 5,000 students to 
complete the second semester starting May $4^{\text {th }}, 2020$ with the support of faculty and especially the students. "The semester seemed to have progressed hopefully it will end well", he said.

Professor Sankat believed that the challenge with Covid-19 and the situation in Belize was a disaster. However, one benefit Belize had over other similar countries was its vast landmass, and its involvement with agriculture. Unfortunately, one issue in Belize was that many of the students had very limited resources. He believed that the country could not be compared to a normal middle-income country in dealing with COVID-19. In addition to not having internet access, students did not have an at-home learning environment. He also believed that the assistance both from the government and other organizations were not forthcoming. While most of the students had access to the internet and other resources it was still an issue in the remote areas. It all boiled down to a lack of resources.

Professor Sankat believed that there needed to be a rapid plunge into the internet and online delivery. "UB could either swim or sink, at the moment the university was swimming.", he said. The question was how well did they perform? "This could be answered through the measurement and evaluation of the students. Students evaluated the teachers." He explained.

His final point was to raise two questions:

1. "Will students return to UB the normal way?"

2. "Will Covid-19 allow for this."

In his opinion, students might not return because of financial challenges, both from parents and sponsors. "It appeared that the Belizean economy had collapsed.", he stated. It was a country that depended on the tourism industry. Due to the pandemic, businesses were closed, and employees were laid off. Although Belize was a small country and only had 21 cases of COVID at the time of the shutdown, it was still not spared by the pandemic. The country depended on global trade which had virtually halted. "How many students would return?", asked Professor Sankat. He estimated that about $20-25 \%$ could be challenged. Generally, he believed that students would be severely tested to return to the new semester.

Due to the COVID-19, Professor Sankat believed that the University of Belize's mission was interrupted, a serious setback for the students. The government's support had been reduced from $\$ 11$ million to $\$ 8.34$ million which had an enormous potential impact at UB given the high percentage of its revenues used to pay the fixed costs of salary and benefits. Prof Sankat predicted that there could be the loss of scholarships. The Regional Language Center (RLC) would also come to a halt, as most of the students were from neighboring Mexico, Columbia, and other Spanish speaking countries.

\section{How was UB attempting to balance its budget?}

According to Prof Sankat, the budget challenge required the attention of both Board of Directors and the Ministry of Education. Given an economy that was dependent on tourism, a lot of pain, deep thinking, and sacrifice would be required at every level. The greatest impediment was finance. Due to the pandemic, he questioned how the programs would be sustained. He believed that it was a time of survival. Skillful leadership was required to support the needs of all stakeholders. That was the main challenge faced by the university.

Additionally, technology was a crucial asset to management and the running of the university. UB would need to invest in technology and learning and administration. The new norm was technology driven. In an environment of learning, technology had become a priority for the institution. The pandemic had also 
interrupted research and outreach, both of which were relevant to teaching. Research required a separate source of funding that required sponsors and donors.

Finally, Prof Sankat assumed that normal campus life would be changed. Covid-19 revealed that economic models failed when the economy was based on a single area of enterprise. There was nothing to fall back on. Leaders needed to diversify their economies. For example, the agricultural sector was great in the Caribbean, however, there needed to be a link between agriculture and manufacturing. Areas of manufacturing were required, and this would increase employment and foreign exchange. Regarding UB, its graduates should be critical thinkers. According to Prof Sankat, the university should get involved in the industry to help make it sustainable.

There was so much learning from the Covid-19 experience. Food security was a major issue. Food as well as public health. COVID was not yet a major issue in Belize. If it were, the country would not be prepared. In Prof Sankat's view, Covid-19 was an awakening for all of Belize.

\section{Student Perspective}

The students' experience in Belize varied depending on their location, economic status, and many other factors. "This pandemic had affected us significantly," said one student. "Covid-19 had caused significant changes and the lecturer's consideration with the students was highly appreciated." Another student said, "in the village where I was living it was very challenging, I only had data on my phone and the internet service was unstable... When completing a test, I needed to type on my phone which took a long time." Another extreme case was a student who had to seek assistance from several neighbors simply to submit one quiz due to the inconsistency in internet service.

\section{Lecturer's Perspective}

There were several challenges and glitches that lecturers experienced with Covid-19 and the university's switch to online modality. At the University of Belize, there were four faculties. Each faculty was governed by its dean and each dean was represented by various chairs located at the different branches (University of Belize, 2018). The chairs were responsible for full-time and part-time faculty located in his/her location (see Exhibit 6). In one emergency faculty meeting, faculty members presented their experiences regarding the delivery of on-line classes. From that one meeting, it became clear there could not be a consistent strategy used to deliver the courses since each member had his/her own experience and reality. One lecturer in a remote area could only e-mail students graded assessments since her access to the internet was minimal. Like some of the students she only had data available on her phone. Another lecturer had never delivered courses online and could only use e-mail as well for graded assessment. Other lecturers believed that the university's main online platform was not effective and hence had to find other means to deliver their courses to the students.

\section{Initial Decisions}

As early as March 13, 2020, the President of the University of Belize made some significant decisions due to the COVID-19 Pandemic. President Sankat's overall reason for implementing an action plan and executing a decision was based on the government's directives. What follows is an explanation of three decisions made from the perspective of Professor Sankat:

1. Immediate response was to wait. The first decision was for the university to wait for directives from the government of Belize as to when it was fit to continue with classes. The first decision 
made by Professor Sankat was on March 17, 2020, when the President announced that by the end of March $20^{\text {th }}, 2020$ the University of Belize would close its doors. Even though Professor Sankat was the President of the National University, the final decision was based on the approval of the board of trustees.

a. Benefits- One benefit to close its doors gave Prof Sankat and the decision-making body sufficient time to decide on its way forward. During this time Prof Sankat along with the deans and chairs decided to conduct a survey. If eighty percent or more of the student population had access to the internet, then the university would proceed online. The students who were unable to proceed online were asked to either withdraw from the course or apply for an audit (AU). The benefits to the students would be that students could continue the course the following semester or when the course was offered. There would be no financial implication.

b. Drawback - the drawback was that students already completed $70 \%$ of the course and it could cost the university since the university still had to pay full-time and part-time faculty the same pay with less revenue from students.

2. Proceed with online classes and assist most of the students. When the university of Belize was informed to close its doors other universities in the world were already on board with online classes. After the first two weeks without any classes and not receiving assurance from the government, the university of Belize decided to send out a survey to students to determine whether an online class is possible based on the percentage of positive response. This was done immediately since its results would determine the effective continuation of the university.

a. Benefit - the benefit to this was that the classes would continue and there would be no interruption in classes. Students could enjoy their summer vacation and faculty could also get a break before the upcoming semester.

b. Drawback - Not all students would be able to continue online. Based on the results from the survey about $80 \%$ of the students were able to complete the classes online. Most of the students who were unable to complete the courses online were residing in the remote parts of the country.

Not all Faculty were prepared to deliver courses online and hence a quick online training for instructors was necessary. If instructors did not perform well and students were not satisfied this could be a disadvantage to the university.

Even before COVID-19, most students were hesitant about signing up for courses online therefore, the results and evaluation of these online courses were important for the university.

3. Seek assistance from the government - Contact the internet service providers to create hotspots for the students who did not have access to the internet. Most of these areas were in the remote villages in the Toledo District.

a. Benefit - If these students' needs were met this would enable the university to reach out to most of the students.

b. Drawback - The overall effect could only be determined until after the semester was complete.

\section{Possible Alternatives/Future Decision}

The initial actions taken by the university were demanded by the urgency of the situation. Since COVID19 was not going away any time soon, however, longer time horizons were now needed. Looking forward, President Sankat considered some of the challenges that needed to be addressed. 
1. One of the first alternatives was for the University of Belize to prepare a contingency plan for turbulent times. Like its hurricane preparedness plan and fire drills, the university needed to strategically identify how it would deal with other unforeseen circumstances such as Covid-19 or another prolonged epidemic or pandemic.

a. Benefit - This would help with the smooth running and transition of the university during chaotic times.

b. Drawback - This process would be costly and time-consuming. Moreover, turbulence was intrinsically unpredictable. What type of plan could cover the full range of possibilities?

2. The other alternative was to determine a self-sustaining strategy. As of the date of this case, the University of Belize's annual subvention was cut from BZ\$11 million to BZ\$ 8.333 million. This would extend up to March 2021. Also, the projection was that there would be a significant reduction in income of $\$ 7.16$ million or $27.3 \%$. A recommendation to assist the university was for the University of Belize to create a business incubator, partner with the manufacturing sector in the country, and to continue with its consultancy unit.

a. Benefit - Even during challenging times the university would be able to pay all faculty and staff and create stability and security among this staff.

b. Drawback - Some of these ventures could be risking and could cost the university more than it was spending.

According to Professor Sankat, the University of Belize had a financial plan for the next six months however, but the future financial health of the university was unpredictable. Were there other alternatives that should be considered to address the current crisis and potential crises in the future. 


\section{References}

Barrow, D. (2019, March 15). Budget Speech for Fiscal Year 2019/2020. Retrieved from https:/www.nationalassembly.gov.bz/wp-content/uploads/2019/03/Budget-Speech-FiscalStrategy-Statement-2019-FINAL.pdf

Basilaia, G., and Kvavadze, D. (2020). Transition to Online Education in Schools during a SARS-COV-2 Coronavirus (COVID-19) Pandemic in Georgia. Pedagogical Research 5(4), doi: $10.29333 / \mathrm{pr} / 7937$

Belize Hub. (n.d.). Map of Belize. Retrieved from https://www.belizehub.com/belizecommunications/map-of-belize/

Chow, J. T. S. (2019). Tourism in Belize: Ensuring Sustained Growth. Retrieved from file://C:/Users/Cindy\%20Thompson/Downloads/wpiea2019267-print-pdf\%20(1).pdf

IGI Global (May 15, 2020). The Uncertain Future of Research Funding and Library Budgets. Retrieved from https://www.igi-global.com/newsroom/archive/uncertain-future-research-fundinglibrary/4577?utm_source $=$ IGI+Global+Products + and + Publishing + Opportunities\&utm campaign $=\mathrm{d} 6 \mathrm{cc} 54 \mathrm{fd} 24-$

EMAIL_CAMPAIGN_Research_Trends_1_19_wk1_COPY 01\&utm medium=email\&utm ter $\underline{m}=0$ bcbd627034-d6cc54fd24-49588333

International Labour Organization (2020). An employers' guide to managing your workplace during COVID-19. Retrieved from https://www.belize.org/wp-content/uploads/ILO-Guide-toEmployers-Covid-19.pdf

Parks, R. A. (2020, May 6). Belize tourism industry faces hard times. Amandala, pp. 1. Retrieved from https://amandala.com.bz/news/belize-tourism-industry-faces-hard-times/

Reimers, F., Schleicher, A., Saavedra, J., \& Tuominen, S. (2020). Supporting the continuation of teaching and learning during the COVID-19 Pandemic. Oecd, 1(1), 1-38.

The University of Belize. (2018). 2017-2018 annual report. Retrieved from https://www.ub.edu.bz/about-ub/annual-report/?wpdmc=ar

\section{Acknowledgment}

This case study is based upon work supported by the President of the University of Belize - Professor Clement Sankat and my Case Study Publication Course Professors - Prof. Matthew Mullarkey and Prof. Clinton Daniel. I would also like to extend my appreciation to Dr. Grandon Gill. 


\section{Biography}

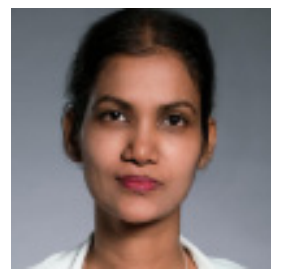

Cindy has been in the teaching profession for the past eleven years, seven of which were at the University of Belize. She also worked at two reputable accounting firms in Belize and the banking sector. Her research interest is in finance and accounting related topics. As part of her job at The University of Belize, she coordinates Accounting and Finance courses and organizes lecturer series on business-related topics. Thompson earned an MBA with a concentration in Finance from Galen University and a bachelor's degree in Accounting from the University of Belize. She completed seven courses in the DBA Advanced Accounting program at North Central University and is currently pursuing a DBA for business professionals at the University of South Florida. 


\section{Exhibit 1: Map of Belize}

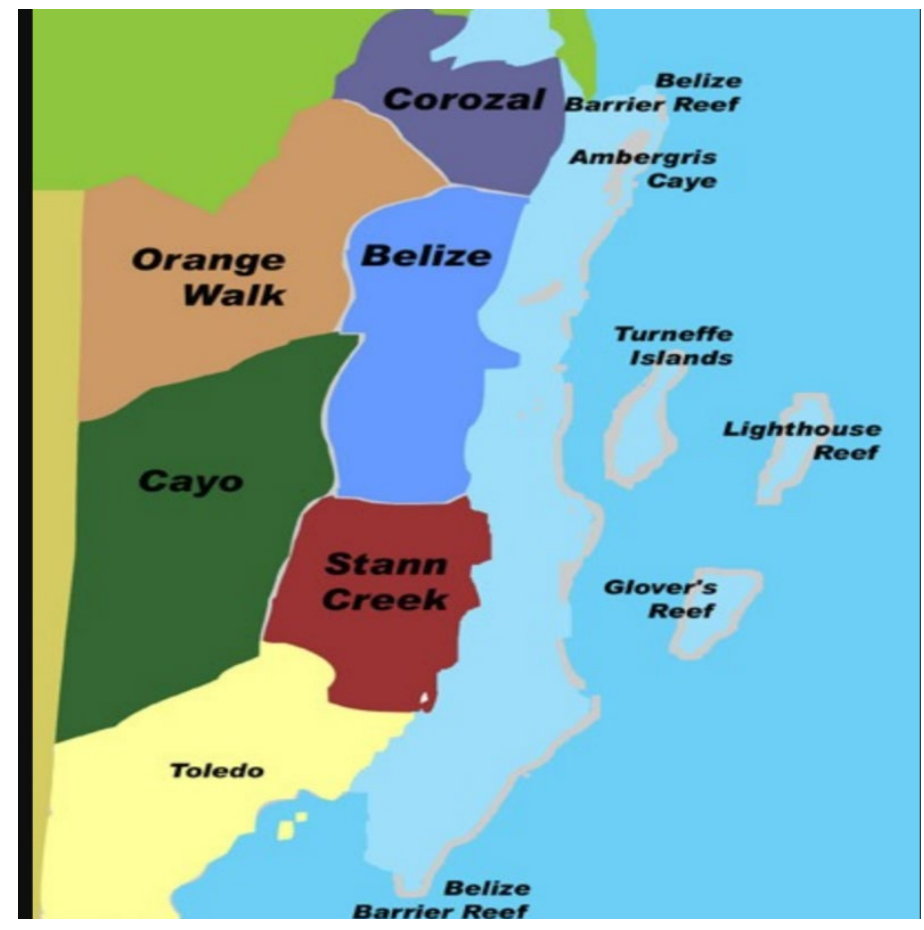

Source: Belize Hub, n.d.

Toledo District - Toledo Campus

Cayo District - Belmopan Central Campus and Central Farm Campus

Belize District - Belize City Campus 


\section{Exhibit 2: UB at a Glance}

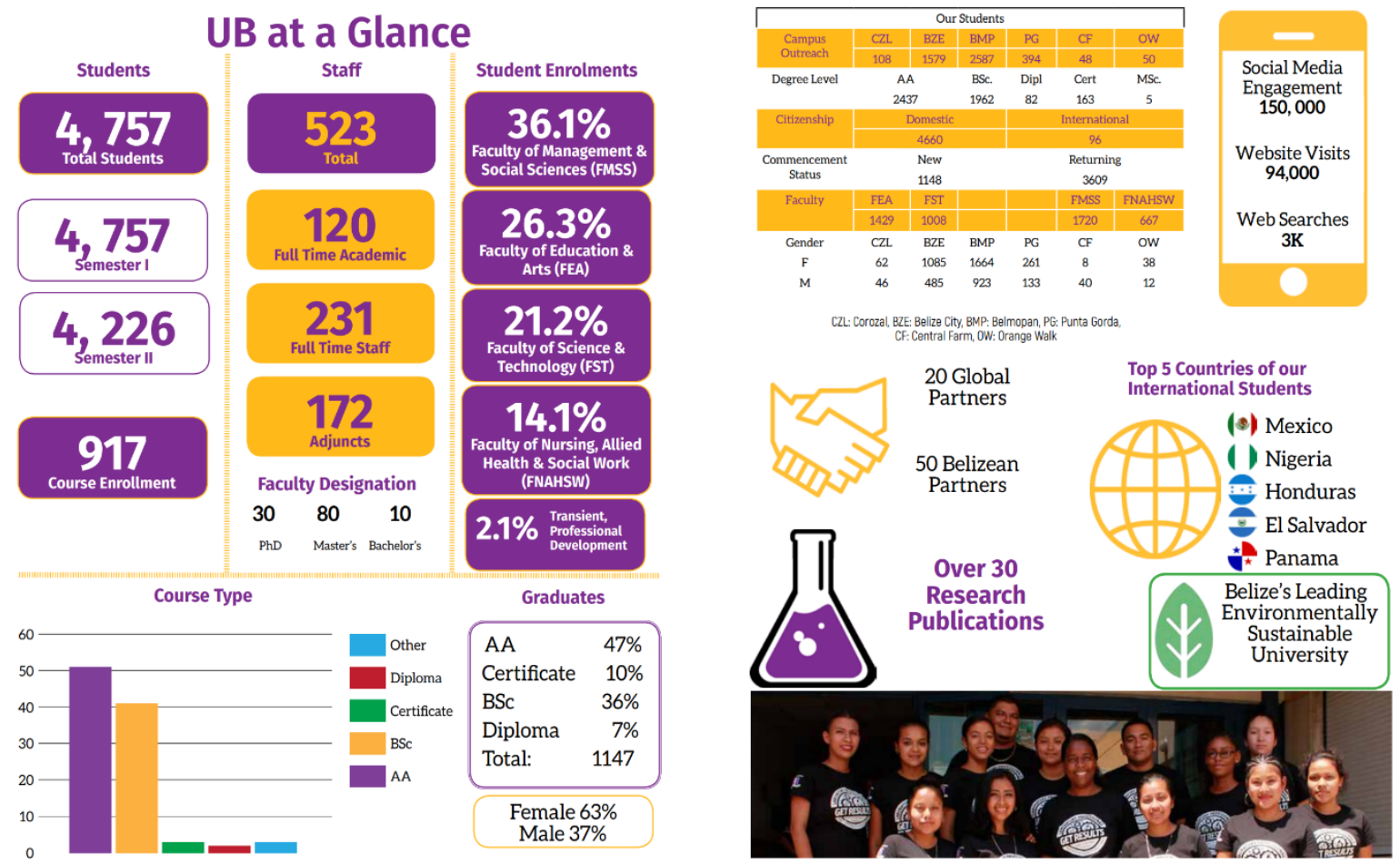

Source: University of Belize. (2018, p. 12, 13) 


\section{Exhibit 3: University of Belize, 2017-2018 Annual Report}

\section{UNIVERSITY OF BELIZE}

STATEMENTS OF FINANCIAL POSITION JULY 31, 2018 AND 2017 (IN BELLZE DOLLARS)

\begin{tabular}{|c|c|c|c|}
\hline ASSETS & $\underline{\text { Notes }}$ & $\underline{2018}$ & 2017 \\
\hline \multicolumn{4}{|l|}{ CURRENT ASSETS: } \\
\hline Cash and cash equivalents - unrestricted & $2 g, 3$ & \$ $1,344,882$ & $\$ 1,492,893$ \\
\hline Cash and cash equivalents - restricted & 29.4 & 344,119 & 495,130 \\
\hline Short term investments - unrestricted & 29,5 & 466,288 & 393 \\
\hline Short term investments - restricted & $2 g, 6$ & $2,745,425$ & $2,866,2$ \\
\hline Students receivables - net & 29.7 & 430,288 & 665,7 \\
\hline Government of Belize receivables & $2 g, 8$ & 5,976 & OA \\
\hline Prepayment & $2 g$ & 225,095 & 208,9 \\
\hline Other receivables & $2 g$ & 237,120 & 170,1 \\
\hline Employee loans and advances & $2 g$ & 56,453 & 68,0 \\
\hline Inventory & $2 h, 9$ & 660,662 & 733,1 \\
\hline \multicolumn{2}{|l|}{ Total current assets } & $6,516,308$ & $7,178.9$ \\
\hline \multicolumn{4}{|l|}{ NON-CURRENT ASSETS: } \\
\hline Other asset & 10 & 877,111 & 956,23 \\
\hline Equity investment in associate & $2 k, 12$ & 450,000 & 450,00 \\
\hline Other investments & $2 g, 2 \mathrm{~L}$ & 100,000 & 100,00 \\
\hline Property, plant and equipment - net & $2 \mathrm{i}, 11$ & $93,937,971$ & $70,842,32$ \\
\hline Total non-current assets & & $95,365,082$ & $\underline{72,348,5}$ \\
\hline TOTAL ASSETS & & $\$ 101,881,390$ & $\$ 79.527 .5$ \\
\hline \multirow{2}{*}{\multicolumn{4}{|c|}{$\begin{array}{l}\text { LIABILITIES AND FUND BALANCES } \\
\text { CURRENT LIABILITIES: }\end{array}$}} \\
\hline & & & CURRENT LIABILITIES: \\
\hline Line of credit & $2 g, 13$ & 30,052 & \$ 64,100 \\
\hline Accounts payable & $2 g .14$ & $3,542,203$ & $2,416,11$ \\
\hline \multirow{2}{*}{$\begin{array}{l}\text { Gratuty and severance payable - current portion } \\
\text { Total current liabilities }\end{array}$} & 15 & 199,825 & 149,01 \\
\hline & & $3,772,080$ & 2.629 .2 \\
\hline \multicolumn{4}{|l|}{ NON-CURRENT LIABILITIES: } \\
\hline Gratuity and severance payable & 15 & $6,020,140$ & $5,036,24$ \\
\hline Deferred income & 16 & 872,532 & $1,781,05$ \\
\hline Deferred grant & $2 m$ & $\dot{0}$ & 79,12 \\
\hline Total non-current liabilities & & $6,892,672$ & 6,896 \\
\hline Total liabilities & & $10,664,752$ & 9.525. \\
\hline \multicolumn{4}{|l|}{ FUND BALANCES: } \\
\hline Capital grant & 20,17 & $29,920,696$ & $28,805,688$ \\
\hline Revaluation surplus & 18 & $62,226,157$ & $40,675,54$ \\
\hline General fund & & $(930,215)$ & 520,6 \\
\hline Total fund balances & & $91,216,638$ & $70,001,8$ \\
\hline TOTALL LIABILITIES AND FUND BALA & & $\$ 101,881,390$ & $\$ 79.52$ \\
\hline
\end{tabular}

The financial statements on pages 3 to 6 were approved and authorized for issue by the President on behalf of the Board of Trustees on April 25,2019 and are signed on its behalf by:
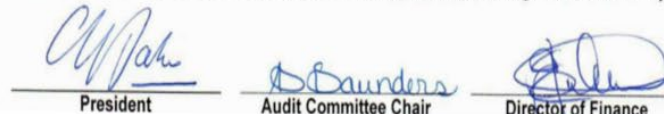

UNIVERSITY OF BELIZE

STATEMENTS OF COMPREHENSIVE INCOME YEARS ENDED JULY 31, 2018 AND 2017 (IN BELIZE DOLLARS)

\begin{tabular}{|c|c|c|c|}
\hline & $\underline{\text { Notes }}$ & $\underline{2018}$ & $\underline{2017}$ \\
\hline $\begin{array}{l}\text { OPERATING REVENUES: } \\
\text { Tution and fees } \\
\text { Other } \\
\text { Government subvention } \\
\text { Amortization of capital grant }\end{array}$ & $\begin{array}{c}2 m \\
2 m, 19 \\
2 m, 2 e \\
20\end{array}$ & $\begin{array}{r}\$ 12,304,107 \\
3,311,360 \\
9,999,996 \\
\quad 632,992 \\
\underline{26,248,455} \\
\end{array}$ & $\begin{array}{r}\$ 10,508,146 \\
3,892,885 \\
9,999,996 \\
626,417 \\
\underline{25,027.444} \\
\end{array}$ \\
\hline $\begin{array}{l}\text { OPERATING EXPENSES: } \\
\text { General and administrative } \\
\text { Educational services and facilities } \\
\text { Depreciation } \\
\text { Employee benefits } \\
\text { Loss on de-recognition of property }\end{array}$ & $\begin{array}{c}2 n \\
2 n, 20 \\
2 n, 21 \\
2,11 \\
22 \\
2 i, 11\end{array}$ & $\begin{array}{r}2,764,457 \\
3,279,325 \\
1,426,041 \\
20,318,188 \\
\frac{\cdot}{27,788,011}\end{array}$ & $\begin{array}{r}2,858,503 \\
4,065,279 \\
1,426,302 \\
19,237,330 \\
\frac{3,440,000}{31,027,414} \\
\end{array}$ \\
\hline LOSS FROM OPERATING ACTIVITIES & & $(1,539,556)$ & $(5,999,970)$ \\
\hline $\begin{array}{l}\text { NON-OPERATING REVENUES: } \\
\text { Interest earned and investment income }\end{array}$ & & 88,678 & 110,114 \\
\hline LOSS FOR THE YEAR & & $(1,450,878)$ & $(5,889,856)$ \\
\hline OTHER COMPREHENSIVE INCOME & 11,18 & $\underline{23,298,617}$ & . \\
\hline TOTAL COMPREHENSIVE INCOME (LOSS) & & $\$ 21,847,739$ & $\$(5,889,856)$ \\
\hline
\end{tabular}

Source: University of Belize. (2018, p. 82, 83) 
MUMA CASE REVIEW

Exhibit 4: Belize Budget For Fiscal Year 2019/2020

SumMARy OF ReCURRENT AND CAPITAL BUdGets

\begin{tabular}{|c|c|c|c|c|}
\hline & $\begin{array}{c}\text { ACTUAL } \\
\text { OUT-TURN } \\
2017 / 18\end{array}$ & $\begin{array}{c}\text { APPROVED } \\
\text { BUDGET } \\
2018 / 19\end{array}$ & $\begin{array}{l}\text { PROJECTED } \\
\text { OUT-TURN } \\
2018 / 19\end{array}$ & $\begin{array}{c}\text { DRAFT } \\
\text { BUDGET } \\
2019 / 20\end{array}$ \\
\hline TOTAL REVENUES AND GRANTS & $1,111,454,839$ & $1,183,327,175$ & $1,174,349,123$ & 1,226,771,198 \\
\hline RECURRENT REVENUE & $1,079,432,196$ & $1,134,914,949$ & $1,144,288,264$ & $1,198,915,868$ \\
\hline TAX REVENUE & $967,445,481$ & $1,022,580,052$ & $1,046,022,903$ & $1,088,786,237$ \\
\hline INCOME \& PROFITS & $270,222,939$ & $277,321,572$ & $288,996,863$ & $305,023,302$ \\
\hline TAXES ON PROPERTY & $6,383,939$ & $6,421,331$ & $6,313,567$ & $6,439,838$ \\
\hline TAXES ON INTERNATIONAL TRADE \& TRANSACTIONS & $157,807,938$ & $170,295,554$ & $167,705,887$ & $167,019,037$ \\
\hline TAXES ON GOODS \& SERVICES & $533,030,666$ & $568,541,595$ & $583,006,587$ & $610,304,060$ \\
\hline NON-TAX REVENUE & $111,986,715$ & $112,334,897$ & $98,265,361$ & $110,129,631$ \\
\hline PROPERTY INCOME & $20,832,481$ & $30,020,584$ & $13,754,922$ & $14,030,021$ \\
\hline LICENCES & $20,334,675$ & $16,947,328$ & $21,619,641$ & $22,052,034$ \\
\hline ROYALTIES & $45,940,248$ & $39,748,006$ & $35,079,569$ & $45,680,123$ \\
\hline OTHER GOVERNMENT MINISTRIES & $24,390,658$ & $24,976,996$ & $27,605,015$ & $28,157,116$ \\
\hline REPAYMENT OF OLD LOANS & 488,651 & 641,983 & 206,213 & 210,338 \\
\hline CAPITAL REVENUES: & $1,798,984$ & $3,300,908$ & $2,506,225$ & $2,556,349$ \\
\hline SALE OF EQUITY & 193,745 & 202,122 & 126,354 & 128,881 \\
\hline SALE OF CROWN LANDS & $1,605,239$ & $3,098,786$ & $2,379,871$ & $2,427,468$ \\
\hline GRANTS & $30,223,659$ & $45,111,318$ & $27,554,634$ & $25,298,981$ \\
\hline TOTAL EXPENDITURES & $1,160,918,767$ & $1,208,717,414$ & $1,185,894,997$ & $1,256,208,969$ \\
\hline TOTAL RECURRENT EXPENDITURE & $1,006,597,949$ & $1,051,353,704$ & $1,028,399,545$ & $1,077,000,794$ \\
\hline PERSONAL EMOLUMENTS & $426,107,271$ & $431,681,060$ & $432,295,633$ & $440,596,070$ \\
\hline PENSIONS \& EX-GRATIA & $94,672,377$ & $91,428,047$ & $96,038,393$ & $97,113,118$ \\
\hline GOODS \& SERVICES & $210,906,621$ & $238,375,250$ & $227,352,086$ & $250,172,089$ \\
\hline SUBSIDIES AND CURRENT TRANSFERS & $172,725,170$ & $177,968,300$ & $175,267,159$ & $174,045,978$ \\
\hline DEBT SERVICE-INTEREST \& OTHER CHARGES & $102,186,511$ & $111,901,047$ & $97,446,274$ & $115,073,538$ \\
\hline TOTAL CAPITAL EXPENDITURES & $154,320,818$ & $157,363,710$ & $157,495,452$ & $179,208,175$ \\
\hline CAPITAL II EXPENDITURES & $59,176,486$ & $61,920,948$ & $61,343,078$ & $74,777,640$ \\
\hline CAPITAL III EXPENDITURES & $92,845,707$ & $93,144,138$ & $87,853,751$ & $96,131,911$ \\
\hline CAPITAL TRANSFER \& NET LENDING & $2,298,624$ & $2,298,624$ & $8,298,624$ & $8,298,624$ \\
\hline RECURRENT SURPLUS/[DEFICIT] & $72,834,247$ & $83,561,245$ & $115,888,720$ & $121,915,074$ \\
\hline PRIMARY SURPLUS/[DEFICIT] & $52,722,583$ & $86,510,808$ & $85,900,400$ & $85,635,767$ \\
\hline As Percentage of GDP & $1.44 \%$ & $2.22 \%$ & $2.21 \%$ & $2.12 \%$ \\
\hline OVERALL SURPLUS/[DEFICIT] & $(49,463,928)$ & $(25,390,239)$ & $(11,545,874)$ & $(29,437,771)$ \\
\hline As Percentage of GDP & $-1.35 \%$ & $-0.65 \%$ & $-0.30 \%$ & $-0.73 \%$ \\
\hline AMORTIZATION & $(83,164,734)$ & $(92,711,964)$ & $(94,739,307)$ & $(103,011,334)$ \\
\hline FINANCING & $(132,628,662)$ & $(118,102,203)$ & $(106,285,181)$ & $(132,449,105)$ \\
\hline GDP (in billions of Bz) (Current prices) & 3.665 & 3.902 & 3.888 & 4.030 \\
\hline
\end{tabular}

Source: Barrow, D. (2019, March 15, p. 2) 


\section{Exhibit 5: The University of Belize: Vision, Mission, and Transformation}

\section{The UB VISION}

The University of Belize is committed to being a recognized University in the region and the premier degree-granting University in Belize, responding to national development needs and priorities of Belize and its aspirations for higher education.

The UB

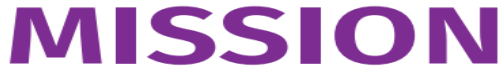

The University of Belize is committed to excellence in higher education, research and service for Belize's national development.

\section{Transformation: The Way Forward}

The University of Belize, in the past 18 years, has contributed, in a substantive way, to Belize's development. As Belize's national university, it shall be the choice university for Belize's most talented and exceptional students, using its teaching and learning framework to transform its students into accomplished and innovative graduates.

As the University looks towards the future, it will ask: how can it best address the current human resource, development and research needs so as to make Belizeans competitive in the global system?

To become a service-oriented and student centered University that addresses the challenges of Belize and Belizeans, the University of Belize will increasingly focus, in the next five years, on
9 strategic priorities as articulated in its strategic plan - A Transformational Leap: Vision 2022.

The University will advance its transformative activities across four core pillars:

\section{Our Four "Rs"}

Relevance

offering students, a global education where they are and where they want to go

$$
\text { Responsiveness }
$$

Meeting the current and future national needs through innovation, outreach, service and research

$$
\text { Reach }
$$

Engaging with and strengthening our communities, enabling our partners and enhancing our enterprises, both local \& International

Responsibility

Operating an efficient, cost-effective \& sustainable University

Source: University of Belize. $(2018$, p. 8, 9) 


\section{Exhibit 6: University of Belize Organizational Structure}

Board of Directors - President - Vice President - Deans - Chairs - Full-time and adjunct faculty

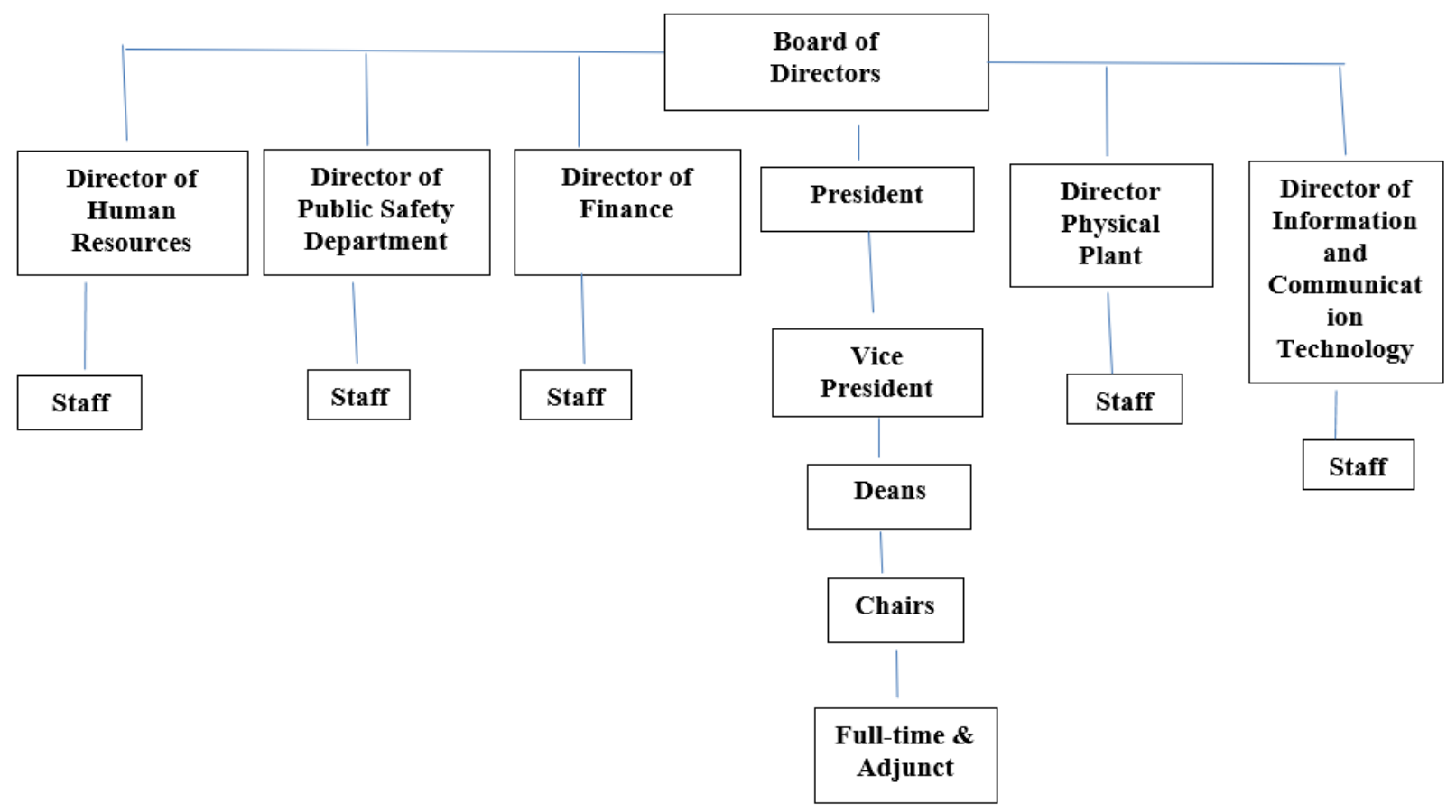

Source: Developed by Case Writer 